\title{
Israel's Nation-State Law - What Now for Equality, Self-Determination, and Social Solidarity?
}

Tamar Hostovsky Brandes

2018-11-09T16:00:21

The enactment of Basic Law: Israel as the Nation State of the Jewish People ("the Law") on July $19^{\text {th }}, 2018$, triggered an intense public debate in Israel. In this post, I argue that the Law is damaging in at least three areas: in serving as pretext for discrimination, in violating the right of Israel's Arab-Palestinian minority to internal self-determination, and in hindering the possible development of all-encompassing social solidarity in Israel.

Opponents of the Law refer to it as racist, shameful and disgraceful, and demand its immediate repeal. Eight petitions against the Law have been filed, as of October 1, 2018, to the Israeli Supreme Court. The petitions argue that the Law is discriminatory and is premised on the subordination of minorities. The notions of exclusion and offence recur in all petitions. In public debate, it was also suggested that the Law is intended to guarantee Jewish superiority in the entire territory of Israel, should unilateral annexation of the Occupied Territories take place (a hypothesis which, for space considerations, I will not discuss).

Proponents of the Law argue that it is a legitimate legal entrenchment of the right of the Jewish people to self-determination, which is, they argue, the justification for the establishment of the state of Israel. They argue that the Law does not violate the principle of equality, which is entrenched, albeit inexplicitly, in Basic Law: Human Dignity and Liberty. They further argue that it is necessary in order to balance Supreme Court's alleged preference of "universal values" over national interests and values.

The Law includes 11 articles. Article 1 states the land of Israel is the "historic motherland" of the Jewish people, that the state of Israel is the nation-state of the Jewish people, where they exercise their right to self-determination, and the right to self-determination in the State of Israel is exclusive to the Jewish people. Article 2 determines the state symbols. Article 3 declares "complete and united" Jerusalem to be the state's capital. Article 4 determines that Hebrew will be the state's language, and that Arabic will be awarded a "special status". Article 5 determines that the state will be open to Jewish immigration. Article 6 establishes the state's commitments to the Jewish diaspora. Article 7 declares Jewish settlement to be a "national value", and states that the state will take actions to promote it. Article 8 determines that the Hebrew calendar will be the official state calendar. Article 9 states the Independence day (Yom Ha'atzmaut) is the official state holiday. Article 10 states that Memorial Day and Holocaust Day are official state memorial days. Article 11 determines that 
the Law can only be changed by a Basic Law accepted by a majority of the members of the Knesset.

\section{The Law's Possible Implications for Individual Equality}

Concerns that the Law will serve as a pretext for discrimination of Israel's nonJewish citizens have been raised both with regard to its general premise, and with regard to specific clauses. The claim with regard to the former is that the Law establishes the superiority of the Jewish majority, and that the general claims regarding "the exclusive right of self-determination" of the Jewish people will serve as ground for future laws that will allow preferential treatment of Jews. By reserving the right of self-determination exclusively to Jews, it is argued, the Law marks members of Israel's national minorities as second-class citizens.

What the Law lacks is, in this regard, as significant as what it includes. The Law includes no reference to equality, and it does not recognize or acknowledge in any other manner the existence of minorities in Israel. Neither of these is an oversight. Alternative versions of the Law, which included an explicit reference to equality, were suggested, and rejected.

During the legislation process, two articles were flagged as raising specific equality concerns. These articles were Article 4, which demotes that status of Arabic from an official language to a "special language", and Article 7, which determines that "the state considers Jewish settlement to be a national value, and it will act to encourage and promote its establishment and development". The latter is perhaps the most controversial article of the Law, and it was heatedly debated. The term "Jewish settlement" is not defined. The debate revolved around whether article 7 would enable the establishment of "Jews only" settlements in Israel, contrary to the Supreme Court's decision in the case of Qua'adan, which determined that the establishment of such settlements violates equality and is prohibited. In addition, it is unclear whether and how article 7 could affect distribution of state resources for the establishments of new cities and villages.

The first judicial decision referring to the Law was recently delivered. It reinforces the concerns regarding the Law's implications for equality. In Messiah v. the Palestinian Authority, the plaintiff sued Hamas for compensation over mental and emotional damages he suffered following a bombing in Tel-Aviv. In evaluating whether the plaintiff should be awarded punitive damages, judge Drori referred to article 6(a) of the Law, which states that "The state will strive to ensure the safety of the members of the Jewish people in trouble or in captivity due to the fact of their Jewishness or their citizenship". Explaining that Hamas targeted Jews as such, judge Drori determines that "when there are a number of available options with regard to punitive damages, and the injured is one of the "members of the Jewish people in trouble or in captivity due to the fact of their Jewishness or their citizenship", the scale will weigh towards awarding punitive damages, among another thing, due to article 6(a) of the Law". Judge Drori further determined that the Law is intended to be operative, 
and not only declaratory, and that being a Basic Law, it applies to the attack despite the fact that it took place twenty years ago.

Because the Law is worded in open-ended terms, its actual effect on equality largely depends on its interpretation, and on how courts will construe the relationship between the different Basic Laws. The Messiah decision demonstrates that the Law may serve as grounds for discrimination in both anticipated and unanticipated ways.

\section{Self-determination and Group Rights}

The notion of self-determination is at the core of the Law, which constitutionally entrenches the statement that Israel is the embodiment of the right of the Jewish people to self-determination. It declares the Land of Israel to be the "historic homeland" of the Jewish people, and states that "the state of Israel is the nationstate of the Jewish people, where it exercises its "natural, cultural, religious and historic right to self-determination". It also determines that "the execution of the right to self-determination in the State of Israel is exclusive to the Jewish people". Despite the centrality of the concept of self-determination, a definition or explanation of selfdetermination is not included.

Following the opinion of the Canadian Supreme Court in re: Quebec, the distinction between external and internal self-determination has taken hold in international law. In Quebec, the Canadian Supreme Court explained that:

"The recognized sources of international law establish that the right to selfdetermination of a people is normally fulfilled through internal self-determination a people's pursuit of its political, economic, social and cultural development within the framework of an existing state. A right to external self-determination (which in this case potentially takes the form of the assertion of a right to unilateral secession) arises in only the most extreme of cases and, even then, under carefully defined circumstances".

While the exact content of the right to internal self-determination is disputed, an explicit denial of the right of minorities to internal self-determination is clearly incompatible with international law. To the extent that self-determination is understood as the right of a people to pursue its collective development, the Law may hinder the recognition of any form of collective rights of the Arab-Palestinian minority in Israel. It may also be used to justify inequality in state funding of initiatives and activities related to such pursuit, and affect the right to political representation, to the extent that such representation strives to achieve collective goals.

\section{Exclusionary Solidarity}

The third type of harm the Law causes is perhaps the most difficult to define. This is the effect the Law has, and is likely to further have, on social solidarity in Israel. The Law purports to constitutionally entrench the national identity of Israel, the 
basis of the relationship between the state and the body-politik. However, it defines the common identity in an exclusionary manner, delineating a bounded solidarity group which encompasses Jews outside of Israel, but excludes Israel's non-Jewish minorities.

Solidarity is the sentiment that renders members of a group willing to bear costs associated with other members' well-being. The importance of solidarity is recognized in connection, for example, with welfare policies, where such costs are tangible. However, many other aspects of societal life also require mutual care and concern, including a willingness to make mutual sacrifices. Those that are not included in the solidarity group are perceived as less-deserving, and as owed weaker obligations. Accordingly, they are also likely to enjoy weaker protection by a society's institutions.

The perception that the Jewish nation, rather than the citizenry of Israel, was the primary solidarity group of Jews in Israel was by no means created by the Law. In fact, this perception was endorsed by Israel's Supreme Court in at least two cases, the 1972 case of Tamarin, and, in 2013, in the case of Ornan.

In Tamarin $v$. the State of Israel, the petitioner applied for a declaratory ruling recognizing his nationality as "Israeli" for the purpose of registration in the population registrar. The Court rejected the petition. Justice Agranat explained that nationhood is characterized by a feeling of unity among its members. "Members of a national unit", he explained, "participate in various aspects of their culture, hold a generally positive attitude towards it, and have a shared desire to be partners in fate and in future aspirations". Members of a national unit, he explained, thus have a "feeling of interdependence" they do not share with outsiders. It is on this notion of interdependence that Agranat based his decision that the petitioner could not belong to an "Israeli nation". To recognize an Israeli nation, explained Agranat, would imply that in Israel a "separation from the Jewish nation" had occurred, which resulted in the creation of a "separate Israeli nation". The mutual interdependence and concern among Jews indicated, according to Agranat, that this has not occurred. As evidence, Agranat stressed the "great concerns of Jews abroad to the safety of Israel and its Jews... their moral and material assistance... and the great anxiety Jews in Israel and abroad have towards the fate of Jews in the Soviet Union...". In order to prove that an Israeli nationality exists, he explained, the petitioner bears the burden to prove that "there are many Jews in Israel... who no longer have the sense of mutual Jewish interdependence....and common responsibility". Agranat concludes that since this has not been proven, neither has the existence of an Israeli nation. The petitioner's request to have his nationality registered as "Israeli" was, accordingly, denied.

In the 2013 case of Ornan the Court reinstated the same observations. "Citizenship", explained Justice Vogelman, "creates a continuing legal connection between the individual and the state... this connection is important in broad areas of law". Nationality, on the other hand, was characterized once again by the "feeling of unity that prevails among the members of the national group... Members of the national group are infused by a sense of interdependence, which also means a sense of common responsibility." The Court repeated the observations made in Tamarin, 
stating that it has not been proven that a sufficiently large group of "people of Jewish origin" in Israel have switched their "sense of common responsibility" from the Jewish nation to the Israeli one. Determining that no proof of such shift has been provided, the Court concluded that, as an empirical fact, an Israeli nation has not been formed.

The Law endorses the Tamarin and Ornan narrative, and takes it a step further. It defines Israel exclusively as the "national home" of the Jewish people, emphasizes Israel's commitment to Jews in the diaspora while refraining from recognizing the existence of minorities or offering a basis for the bond of such minorities to the state of Israel. The result is a constitutional delineation of a political community in which bounded solidarity is presumed to exist, and to which non-Jewish minorities in Israel do not belong.

The Tamarin and Ornon cases are little-known among the general public and their impact on public debate and opinion is, accordingly, negligible. The Law, on the other hand, is a high-profile constitutional act which embraces an exclusionary constitutional identity. I indicated above that that the notions of exclusion and offence dominated the petitions filed against the Law, by individual Palestinian and Druze citizens and by NGOs. The Law conveys an equally problematic message to Israel's Jewish citizens, by implying that their obligations towards their fellow non-Jewish citizens are inferior to those owed to Jews.

It is too early to draw empirical conclusions regarding the actual impact the Law will have on social solidarity between Jews and non-Jews in Israel. What is clear, however, is that the Law accords no importance to the creation of all-encompassing solidarity among Israel's citizens, and that no effort has been made to consider the negative effects the Law may have on such solidarity. 